\title{
Preventing Encounters between Children and Snakes ${ }^{1}$
}

\section{Steve A. Johnson and Martin B. Main ${ }^{2}$}

The most effective way to prevent a child from being bitten by a venomous snake at school or elsewhere is to prevent them from interacting with a snake. We provide measures that can be taken by schools to discourage snakes from coming onto school property and we provide a short educational program that teachers can give to students.

\section{Discourage snakes from entering school grounds}

School administrators can take measures to discourage snakes from entering school property. An effective and inexpensive way to discourage snakes from entering school yards is to erect a silt fence barrier around the perimeter of the school property (Figure 1). Silt fence is the black fabric used around construction sites to control erosion and siltation of wetlands. The material comes in rolls with wooden stakes already stapled to the fabric and is easy to erect. Silt fence is available at most construction and building supply outlets. We recommend burying the silt fence 4-6 inches to prevent snakes from crawling under the barrier.

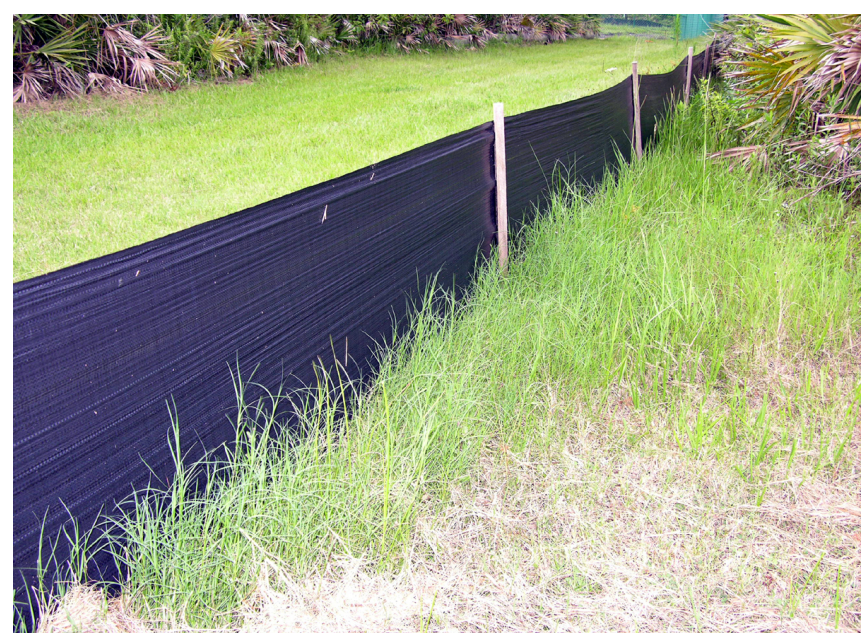

Figure 1. Snake barrier fence. Credits: Steve A. Johnson

If constructing a complete barrier around the school yard is not possible, silt fence can be erected at specific locations where snakes are most likely to access the school yard, such as near wetlands and other natural areas. In these instances, the ends of the barrier should curve back away from the school yard for several meters to direct snakes away from school property. We recommend that the side of the silt fence with stakes face the school yard. Vegetation

1. This document is WEC 201, one portion of a 4-part package of the Department of Wildlife Ecology and Conservation entitled "Dealing with Venomous Snakes in Florida School Yards." Institute of Food and Agricultural Sciences (IFAS), University of Florida. First published: September 2005. Please visit the EDIS Web site at http://edis.ifas.ufl.edu. Accompanying documents are available by contacting Steve A. Johnson (johnsons@wec.ufl.edu) or Martin B. Main (mbma@mail.ifas.ufl.edu). A free PowerPoint presentation (with speaking notes) about venomous snakes in Florida is available upon request from Steve A. Johnson.

2. Steve A. Johnson, Assistant Professor and Extension Specialist, Department of Wildlife Ecology and Conservation, Mid-Florida Research and Education Center, University of Florida's Plant City Campus, 33563; Martin B. Main, Associate Professor and Extension Wildlife Specialist, Department of Wildlife Ecology and Conservation, Southwest Florida Research and Education Center, Institute of Food and Agricultural Sciences, University of Florida, Immokalee, FL 34142.

The Institute of Food and Agricultural Sciences (IFAS) is an Equal Opportunity Institution authorized to provide research, educational information and other services only to individuals and institutions that function with non-discrimination with respect to race, creed, color, religion, age, disability, sex, sexual orientation, marital status, national origin, political opinions or affiliations. U.S. Department of Agriculture, Cooperative Extension Service, University of Florida, IFAS, Florida A. \& M. University Cooperative Extension Program, and Boards of County Commissioners Cooperating. Larry Arrington, Dean 
should be trimmed on both sides of the barrier. Be sure to inspect and maintain the fabric and stakes regularly to ensure there are no gaps under the fabric.

School personnel should monitor the inside of the fence at appropriate times to check for snakes trapped within the school yard. Snakes and other wildlife (e.g., frogs and turtles) found inside the barrier should be captured and released outside the barrier. To ensure their safety, school personnel need to be trained to differentiate between venomous and non-venomous species. We suggest school personnel carry snake tongs and a plastic garbage can with a tight fitting lid. Snakes should be transferred to the garbage can and, with the lid secured, transported away from the school yard and released. Snakes should not be killed, even venomous species. Snakes play an important ecological role and need to be treated with respect. Killing snakes sets a bad example for students and puts personnel at unnecessary risk. Statistics show that people who are attempting to handle, harm, or kill snakes are the most likely victims of snakebite.

An additional way to discourage snakes from school yards is to ensure these areas are not attractive to snakes. Snakes have numerous predators, prominent among them are birds of prey. Risk of predation from hawks and other raptors causes snakes to avoid areas that lack protective cover. We recommend keeping grass and other vegetation short by frequent mowing in areas where children play. Brush piles and debris should be removed from school yards because they are attractive to snakes. We do not recommend using any type of chemical snake repellant.

\section{Educate children}

We encourage schools to teach students about snakes and what to do if they encounter a snake at school or elsewhere. Students should not be taught to fear or hate snakes. It is important that programs instill respect for snakes and the important ecological roles they play in the environment, while emphasizing appropriate behaviors that will protect children from potential injury.

\section{PowerPoint Presentation}

We have prepared an 11-slide PowerPoint presentation for teachers designed to educate students about venomous snakes and to present visual examples of each of the six venomous species that occur in Florida. This information can also be provided verbally without the slide presentation. Notes for each slide are provided. The first four slides teach students

1. about the important ecological roles of snakes,

2. about the potential risks posed by venomous snakes,

3. what they should do if they encounter a snake in the schoolyard, and

4. what to do in the event they are bitten by a snake.

Speaking notes for the first four slides are designed at an elementary level.

The remaining slides showcase the six venomous species of snakes that are found in Florida. Two non-venomous, look-alike species (i.e., mimics) that resemble Coral Snakes are included for comparison. Notes for each slide include statements about each species' range in Florida, habitat preferences, and colors/markings. The slides include images of the following snakes:

1. Cottonmouth/Water Moccasin

2. Copperhead

3. Eastern Diamond-backed Rattlesnake

4. Timber Rattlesnake

5. Pygmy Rattlesnake

6. Coral Snake

7. Coral Snake, Scarlet Kingsnake, Scarlet Snake

Visual recognition slides are appropriate for all ages and may also be provided as handouts. Speaking notes provide teachers with information they can tailor to meet their needs. 
A free $\mathrm{CD}$ with the PowerPoint presentation can be obtained by completing the Dealing with Venomous Snakes in Florida School Yards order form in this packet.

\section{Presentation Speaking Points for the PowerPoint presentation: Venomous Snakes of Florida}

\section{Slide 1. Ecological roles of snakes}

Snakes are important to the Florida environment. Snakes are eaten by many animals, including alligators, hawks, and wading birds. Snakes also eat animals such as mice and rats, insects, lizards, frogs, and other snakes. This cycle of eating some animals and being eaten by others is part of the balance of nature. If we respect nature, we need to respect all the animals that live in nature, including snakes.

\section{Slide 2. Potential risks of snakes}

All snakes can bite but rarely do unless they feel threatened. Given the opportunity, snakes will usually flee. Grabbing a snake or teasing a snake may cause the snake to bite in self-defense. Children look huge to snakes and a snake may perceive a child as a threat. The best thing is to leave snakes alone. You should not be afraid of snakes. You need to respect them and give them their space.

\section{Slide 3. What to do if you encounter a snake}

If you find a snake at school, you need to leave it alone and immediately inform a teacher or an adult that there is a snake in the school yard. Give the snake space and do not attempt to pick it up or step on it. Do not let other children harass or attempt to handle the snake. Remember this phrase about snakes: "leave it be and it won't hurt me."

\section{Slide 4. What to do if bitten by a snake}

If you are bitten by a snake, leave the snake alone and move away from it. Everyone should leave the snake alone. Remain calm, there is no need to panic. Immediately walk to the nearest teacher (or adult) and tell him or her that you have been bitten. If you are with a friend that is bitten, quickly go tell a teacher what has happened. It is important that you or your friend get medical attention as soon as possible.

Of the 45 species of snakes that are native to Florida, only six are poisonous (= venomous). However, you should never attempt to handle, harass, or harm any snake at school or at home.

\section{Slide 5. Venomous snakes in Florida (Cottonmouth, a.k.a. Water Moccasin)}

The Cottonmouth is the most aquatic of Florida's venomous snakes and occurs throughout the state. Although they may exceed five feet in length, most adult Cottonmouths observed in Florida are about three feet long. This species prefers the margins of lakes, rivers, and wetlands. Adults are dark-colored and may have a faint cross-band pattern or be a uniform black. The eye is camouflaged by a broad, dark, facial stripe that runs from the eye to the back of the head. When threatened, Cottonmouths often open their mouths wide, revealing the cotton-white interior. Young Cottonmouths are brightly colored with reddish-brown cross-bands and a yellow-colored tail. When young they look very similar to the Copperhead.

Several species of harmless water snakes are often mistaken as Cottonmouths. Although water snakes are not venomous, they tend to be aggressive and quick to bite. To avoid confusion and the potential for being bitten, it is best to leave all water snakes alone.

\section{Slide 6. Venomous snakes in Florida (Copperhead)}

In Florida, Copperheads only occur in a small area of Florida's Panhandle just west of Tallahassee, primarily along the Apalachicola River and its tributaries. Copperheads prefer to remain near streams and wet areas. A full grown Copperhead is usually less than three feet long. Copperheads are relatively thick-bodied with bold markings. The general body color of these snakes is light brown to gray, and there are large bands of darker brown along their backs. Because of constrictions in the darker bands along the center of the back of this species, the darker bands have an hour-glass shape. The alternating pattern of lighter and darker bands 
provides Copperheads with exceptional camouflage in the forested areas where they live. Young Copperheads look very similar to adults, but the tips of their tails are yellowish in color.

\section{Slide 7. Venomous snakes in Florida (Eastern Diamond-backed Rattlesnake)}

This is a very dangerous snake and should not be approached. The Eastern Diamond-backed Rattlesnake is Florida's largest venomous snake and may exceed six feet in length. It occurs throughout Florida in a variety of dry habitats, such as pinelands, scrub, and golf courses. Eastern Diamond-backed Rattlesnakes have bold markings down their backs that include a row of large dark diamonds with brown centers and cream-colored borders. Their tails end in a rattle that is used to make a loud buzzing sound when the snakes feel threatened. Some individuals may not rattle, even when they are poised to strike. The large, thick head has a light-bordered dark stripe running diagonally through the eye to the rear of the jaw. The scales of this species are strongly keeled (i.e., there is a ridge down the center of each scale), giving these snakes a rough appearance. The young are similar to the adults in color pattern.

\section{Slide 8. Venomous snakes in Florida (Timber Rattlesnake)}

The Timber Rattlesnake (a.k.a. Canebrake Rattlesnake) has a relatively small range in the state; they are only found in northern Florida as far south as Gainesville and in limited portions of the Panhandle. This species prefers moist pinelands, river bottomlands, and hammocks. Timber Rattlesnakes can grow to five feet or longer. These snakes have a pinkish-gray to tan body color with prominent, irregular-shaped dark marks and bands. A reddish-brown stripe runs along the middle of the back of Timber Rattlesnakes. The tail of the species is dark brown or black and ends with a large rattle. Timber Rattlesnakes have large, thick heads and there may be a band from each eye to the rear of the head. The scales of this species are strongly keeled, giving these snakes a rough appearance. The young are similar to the adults in color pattern.

\section{Slide 9. Venomous snakes in Florida (Pygmy Rattlesnake)}

Pygmy Rattlesnakes are the smallest of Florida's venomous snake species. Adults rarely exceed 20 inches in length. Pygmy Rattlesnakes range throughout the state and occur in many different habitats that include pine flatwoods, oak scrub, open pinelands, and palm hammocks. This is one of the most commonly encountered venomous snakes and occasionally is found in residential neighborhoods. They have a dark band running from each eye to the rear of the jaw. Their bodies are covered with numerous dark blotches. There is a row of darker blotches running down the middle of the snake's back. Usually a series of reddish-brown marks can be seen between the blotches on the back. The rattle on the tip of the tail of this species is so small that it cannot be heard even when shaken vigorously by the snake. Pygmy Rattlesnakes are bold and will often hold their ground if approached. They will bob their head and strike into the air if they feel threatened.

\section{Slide 10. Venomous snakes in Florida (Coral Snake)}

Coral Snakes occur in many types of habitats throughout the state but are seldom encountered because they are quite secretive and spend much of their lives underground. They are rarely longer than 30 inches and are usually no bigger around than a quarter. Coral Snakes are identified by the alternating bands of black, yellow, and red that give this species its bold appearance. The head of a Coral Snake has a blunt, black snout followed by a band of yellow.

\section{Slide 11. Non-venomous Coral Snake mimics (Scarlet Kingsnake and Scarlet Snake)}

Two non-venomous species look very similar to Coral Snakes because they also have bands of red, black, and yellow (or white). However, the arrangement of the bands differs between the non-venomous species (Scarlet Kingsnake and Scarlet Snake) and the Coral Snake. In the two non-venomous species the red bands touch only black bands, but in Coral Snakes the red bands only touch yellow bands. Remember the stoplight phrase "yellow, red, STOP!" If the red and yellow bands 
are next to each other, like the colors of a stoplight, it is a Coral Snake.

To obtain a free copy (CD) of the PowerPoint presentation Venomous Snakes of Florida please complete the following information:

Name:

Title:

Organization:

Email:

Mailing Address:

Send order form by mail or e-mail to:

Steve A. Johnson, Ph.D.

University of Florida/IFAS--Plant City Campus

1200 North Park Road

Plant City, FL33563-1540

E-mail: johnsons@wec.ufl.edu (include "Snake Presentation" in Subject line) 